\title{
TWO-PHASE SELECTION PROCEDURE OF ALUMINIZED SHEET SUPPLIER BY APPLYING FUZZY AHP AND FUZZY TOPSIS METHODOLOGY
}

\author{
Harun Bronja, Haris Bronja
}

Original scientific paper This paper presents a new, two-phase, multi-criteria procedure for selection of a supplier of aluminized sheet to be used in the car exhaust system. In the first stage a procedure of modelling the relative importance of weighted criteria using fuzzy AHP (Analytic Hierarchy Process) was carried out, while in the second phase prioritization and selection of suppliers based on the distance from an ideal solution, using the corrected fuzzy TOPSIS (Technique for Order of Preference by Similarity to Ideal Solution) methodology were done. Crisp values criteria were recorded and represented by numbers, and uncertain criteria values were represented by linguistic expressions that were converted into fuzzy numbers. Prioritization was done by comparing values in a descending order. A software solution based on the proposed methodology was done. An illustrated example with real data of sheet provision was also presented.

Keywords: aluminized sheet; fuzzy AHP; fuzzy TOPSIS; supplier

Dvofaznini postupak izbora dobavljača aluminiziranog lima primjenom neizrazite AHP i neizrzite TOPSIS metodologije

Izvorni zanstveni članak

U ovom radu predstavljen je novi dvofazni višekriterijski postupak izbora dobavljača aluminiziranog lima za proizvodnju ispušnih sustava automobila. U prvoj fazi postupka vrši se modeliranje relativnog značaja težinskih kriterija primjenom neizrazite AHP (analitički hijerarhijski proces) metodologije, a u drugoj fazi vrši se prioritizacija i izbor dobavljača na osnovu udaljenosti od idealnih rješenja, primjenom korigirane neizrazite TOPSIS (tehnika za slijed poželjnosti po sličnosti idealnom rješenju) metodologije. Vrijednosti crisp kriterija su snimljene i predstavljene brojčanim vrijednostima, a vrijednosti neizvjesnih kriterija predstavljene su pomoću lingvističkih izraza koji se pretvaraju u neizrazite brojeve. Prioritizacija je izvršena uspoređivanjem vrijednosti u opadajućem nizu. Urađeno je softversko rješenje zasnovano na predloženoj metodologiji. Predstavljen je ilustrativni primjer s realnim podacima nabavke lima.

Ključne riječi: aluminizirani lim; dobavljač; fazi AHP; fazi TOPSIS

\section{Introduction}

In order to maintain their positions at the market and to become competitive among the competitors, companies should push for competitive production. Competitive production means competitiveness in several spheres of business, first of all in the following areas: quality, JIT (Just in Time) production, quick response, low cost, flexibility, standardization of products and services, cooperation with suppliers and customers, and so on. It has been known that the main goal of any enterprise is acquiring the largest possible profit. Profit - making can be achieved only if a buyer purchases the right product. But, to make a buyer choose a particular company's product, not its competitor's one, the mentioned product must satisfy his needs, must have the proper quality and minimal cost price [1]. In many companies the cost of raw materials and purchased parts is $60 \div 70 \%$ of the total cost of the product [2]. Such high costs of purchased aluminized sheet have been increasingly analysed by a number of researchers aiming at their reduction. Many authors have been searching for the possibilities of improving the efficiency and reducing the costs of procurement of aluminized sheet [3]. Some authors (Sreekumar1 and Mahapatra) in [4] have studied the principles of supply from major suppliers and long-term partnerships, in order to get discounts in the price. Kumar, Vrat and Shankar in [5] think that the strategic partnership should integrate better performance of suppliers in the supply chains, to improve performance in various aspects, including reducing costs, eliminating waste, continuous quality improvement and reduce errors, improving flexibility to cater for needs of the final consumers, the reduction of time in the different stages of the supply chain, and so on.

The trend of using larger suppliers and logistic costs made the management focus its concern on procurement function. The traditional understanding of procurement, where the company concentrated on cheap suppliers, has been replaced by a strategy which is based on the quality and concentrating on developing long term relationships with suppliers, the establishments of partnerships to a continuous improvement of product quality and reducing costs. Flexibility as a basic requirement to understand the dynamic markets, followed by a small and very diverse series, is a very important characteristic of suppliers. Their reliability is a guarantee of a stable and long-term cooperation with their partners. These assumptions suggest the existence of a large number of criteria that should be analysed in details with an appropriate application of multiple criteria method, so that the problem of selection of aluminized sheet suppliers could be adequately resolved.

In order to make an objective assessment of the major criteria of suppliers, an expert team consisting of several members most responsible for the organization and procurement, is formed (Mahdavi et al. [6]) in the company for the manufacture of parts of aluminized steel. The team members should have a minimum of 15 years experience in similar jobs in the company. Members of the expert team perform the criteria evaluation, based on professional knowledge, ability, experience and skills. The members of the expert team select the number and type of criteria and evaluate the criteria weights. The values of qualitative criteria are determined on the basis of statistical data, measurement or recording in practice, 
while the quantitative ones can be determined on the basis of the assessment of the management team members. The problem becomes more complex if one takes into account an objective assumption that the considered criteria have different relative importance. Thus, the basic requirement of a procurement organization is to select a reliable method that can be used in the process of selection of suppliers in supply chains of aluminized sheet and in this regard, the main objective of this paper is to propose a multiple criteria method for evaluation and selection of suppliers, using several criteria (qualitative and quantitative) of different relative importance. To solve this problem, the expanded two-phase fuzzy AHP and fuzzy TOPSIS methodology have been proposed. This paper presents the detailed process of selecting the suppliers of aluminized sheet of the companies producing exhaust systems for the car industry. The company procures sheet in a globalized market from domestic and foreign manufacturers. Since the cost of purchased sheet makes a larger part of the total cost of the product, supply managers find the possibility of savings in this area. The savings in this area relate to a more effective assessment and selection of optimal supplier.

The contributions of this paper are as follows: The proposed extended fuzzy TOPSIS method with some improvements in certain steps, such as the applied fuzzy AHP method to determine the weights of criteria; to overcome the uncertainty of decisions taken, the theory of fuzzy sets was applied in the paper; fuzzy assessment of each of the observed criteria by each decision-maker has been described as one of the predefined linguistic expressions; the number and types of linguistic expressions were defined by the decision makers based on their own experience and skills. There were applied positive triangular fuzzy numbers according to Chou and Chang [7]. A procedure of group decision-making was applied [8]. Decisions about the weight of the criteria were made by a group of decision makers. The normalization of fuzzy values in group decision making was performed by using a root mean square. Normalization of the criteria values was done as a linear normalization. Determination of the distance from the ideal solutions was performed by using the corrected distance from the ideal solution (adjusted solution ideal solution) $\mathrm{ASIS}^{+}$and $\mathrm{ASIS}^{-}$.

The rest of the paper was organized in the following way: Chapter 2 contains the overview of literature for multi-criteria approach of supplier selection; Chapter 3 is a mathematical formulation of the proposed model of selection of aluminized sheet supplier; Chapter 4 gives an illustrative example with the concrete values recorded in a company; Chapter 5 contains final observations, and Chapter 6 gives the list of the literature used.

The developed model is a suitable tool for the selection of suppliers in the field of metal-processing industry with regard to the previously mentioned features for the purchase of aluminized steel. Since many members of the expert team who use linguistic variables in the evaluation of suppliers were involved in the process of selection of suppliers, there were achieved substantial savings both in the implementation of the very process and in the selection of the right suppliers. Further research may be directed to the improvement of the proposed model of suppliers' selection in an uncertain environment. Improvements might refer to calculations of the distance from the ideal solutions $A S I S^{+}$and $A S I S^{-}$as well as to application of the fuzzy Delphi method for defining the number and type of criteria and determining the relative weights of criteria. A software solution for the proposed model should also be developed.

\section{Literature review}

The procedure of supplier selection in supply chains systems in various fields of production has been the matter of many researchers' works in recent years. In order to increase the preciseness of researches and include more criteria, researchers are choosing two-phase methods of a supplier selection more and more. Using one method has not given sufficiently precise data, so they have started using two or more methods in two-phase treatment of the problem. The most often used methods are the ones for determination of criteria's relative importance weighting, analytical hierarchy process (AHP) (Saaty) in [9] and the method of comparison to the ideal solutions - TOPSIS method (Hwang and Yoon) in [10].

Fuzzy assessment of each criterion's weight is calculated by various methods. The method of average value is used with integration of fuzzy assessments of all the decision makers into a single criteria value [11]. In Ting-Ya Hsieh et al. [12], standardization of weighted criteria is done by standardization of decision makers' values by geometric mean. In Tadic et al. [1], determination of decision makers' weighted criteria's values was done by Delphi method. In Sreekumar and Mahapatra, [4] fuzzy assessment of weights is based on Nash's negotiation approach based on essential weight estimation. In Mahdavi et al. [6], the decision on criteria's weights is supposed to be made by a consensus achieved among ten decision makers. In Chen et al. [13], aggregate fuzzy assessment of each criterion was calculated by the methods including ranges of all the decision makers' fuzzy assessments. A lot of works suppose that fuzzy assessment of each criterion is described by defined linguistic expressions modelled by triangular fuzzy numbers, Torfi et al. [14]. In the published papers, criteria can be defined as crisp criteria and uncertain criteria. The values of crisp criteria are converted by the maximal value principle (conventional TOPSIS method), while uncertain criteria values are described by linguistic expressions modelled by triangular fuzzy numbers (Chen et al. [13]). The converted values of uncertain criteria are defined on the scale $[0 \div 1]$, Torfi et al. [14].

Some authors have proposed a weighted normalized decision matrix modelled by algebraic rules (Zimmermann [15], Chen et al. [13]). This decision matrix is used to define (positive and negative ideal solutions and fuzzy positive and fuzzy negative ideal solutions) PIS, NIS, FPIS and FNIS. By defining PIS, NIS, FPIS and FNIS values, the limits of distance assessments are defined. Authors use various methods to calculate the distance from ideal solutions. The distance from FPIS and FNIS is calculated by the expressions [16]. The distance from ideal solutions was calculated by Chen, [3] vertex method (Anjali Awasthi et al. [17], Ali Shemshadi et al. [18] and Chen-Tung Chen, et al. [13]). In 
MortezaYazdani, [19] FPIS and FNIS were defined as (1, $1,1)$ and $(0,0,0)$ respectively. The distance of each alternative from FPIS and FNIS was calculated by measuring the distance between fuzzy numbers, Sadeghpour [16]. Determining the distance of fuzzy measures is based on the method developed by (Chakraborty [20]). In Tadic et al. [21], FPIS and FNIS were determined by fuzzy decision matrix by comparison of fuzzy numbers (Dubois and Prade [22], Bass and Kwakernaak [23]) in relation to a kind of a criterion. The distance of each FPIS and FNIS alternative was calculated by the procedure defined by conventional TOPSIS method.

This paper is also based on similar two-phase methods. Determining the relative importance of weighted criteria has been done according to the decision makers' assessments (5 decision makers) and by their relative importance standardization. Fuzzy assessment of each treated criterion of each decision maker was described by one of the previously defined linguistic expressions. The number and kind of linguistic expressions were defined by the decision makers on the basis of their own previous experience and data on that problem. Modelling of these linguistic expressions was based on fuzzy set theory. Standardization of weighted criteria values was done by square mean and determining the distance from ideal solution was done by corrected TOPSIS method. The values $A S I S^{+}$and $A S I S^{-}$were qualified as a way of improvement of TOPSIS method.

\section{Mathematical formulation}

\subsection{Defining criteria for aluminized sheet supplier selection}

On the basis of supply manager's experience, the surveys that were carried out in the enterprise, as well as on the basis of this paper's personal author's observations, the criteria for supplier selection were defined as follows: product price, time of delivery, way of payment, quality of material, supplier's reliability, supplier's flexibility, material ecological safety, supplier's location, previous relations to suppliers and supplier's development prospects. The criteria values are, in fact, buyer's demands values, so that the provision process could provide with a normal production process and competiveness of ready products at the market, while materials, information and capital could have a continuous flow. The description and modelling of criteria was presented in details in Chapter 3.3.

\subsection{Weights modelling}

In this paper, the supplier criteria fuzzy assessment for each pair of the proposed criteria was described by linguistic expressions that can be presented as a triangular fuzzy number $\widetilde{W}_{k k}=\left(x ; l_{k k}, m_{k k}, u_{k k}\right)$ with the lower and upper bounds $\mathrm{l}_{\mathrm{kk}}$ and $\mathrm{u}_{\mathrm{kk}}$ and modal value $\mathrm{m}_{\mathrm{kk}}$, respectively. The values in the domain of these triangular fuzzy numbers belong to the real set in the scale $[1 \div 5]$ or $[1 \div 3]$

Values of fuzzy weighted coefficients were calculated by the following formula:

$\widetilde{W}=\left(W_{j 1}, W_{j 2}, \ldots, W_{j k}, \ldots, W_{j K}\right)$
In this paper, the fuzzy rating of each decision maker can be described by five linguistic expressions. These linguistic expressions were modelled by triangular fuzzy numbers which were described in the following way:

- Equally important $\mathrm{R} 1=(x ; 1,1,3)$

- Moderately important $\mathrm{R} 2=(x ; 1,3,5)$

- Strongly important $\mathrm{R} 3=(x ; 3,5,7)$

- Very strongly important $\mathrm{R} 4=(x ; 5,7,9)$

- Extremely important $\mathrm{R} 5=(x ; 7,9,9)$

The procedure of calculating weighted criteria for aluminized sheet supplier selection for the 10 proposed criteria was done in the following way: a team of five groups of decision makers, each consisting of 3 members, was formed. Decision makers for evaluation of the criteria of supplier selection in this paper were: general manager of the company with his associates, supply manager experts, quality control manager, the company's financial experts and production manager with his associates.

Determining relative importance of weighted criteria was calculated in the following steps:

Step 1. On the basis of decision makers' assessments ( 5 decision makers) of relative importance of weighted criteria, a pair wise comparison matrix was formed. Comparison matrix among all assessment elements/criteria was formed in the hierarchical system dimensions by use of the decision makers' linguistic expressions.

Step 2.Conversion of linguistic expressions into fuzzy numbers was carried out by fuzzy numbers defined for linguistic expressions.

Step 3. Calculation of pairwise comparison matrix elements was done by square mean, as proposed by the author. Five proposed decision matrices were led to the one matrix, by the following formula:

$\tilde{a}_{i j}=\sqrt[n]{\frac{\left(\tilde{a}_{i j}^{1}\right)^{2}+\left(\tilde{a}_{i j}^{2}\right)^{2}+\cdots+\left(\tilde{a}_{i j}^{n}\right)^{2}}{n}}$,

where:

$\tilde{a}_{i n}$ - value of fuzzy comparison of criterion $i$ in relation to criterion $n$.

Step 4. Value $\tilde{r}_{i}$ was calculated by the use of mean square Eq. (2).

$\tilde{r}_{i}=\sqrt[n]{\frac{\left(\tilde{a}_{i 1}\right)^{2}+\left(\tilde{a}_{i 2}\right)^{2}+\cdots+\left(\tilde{a}_{i n}\right)^{2}}{n}}$

Step 5. By using the Eq. (3), we calculated values of fuzzy weight of i criterion $\widetilde{W}_{i}$.

$\widetilde{W}_{i}=\frac{\tilde{r}_{i}}{\tilde{r}_{1}+\tilde{r}_{2}+\cdots+\tilde{r}_{n}}$

where:

$\tilde{\mathrm{r}}_{\mathrm{i}}$ - is value of mean square of fuzzy comparison criterion $i$ in relation to any criterion,

$\widetilde{\mathrm{W}}_{\mathrm{i}}$ - is fuzzy weight of $i$ criterion.

Values $\widetilde{W}_{i}$, calculated in this way are weighted criteria values of the corrected fuzzy AHP method. 


\subsection{Criteria modelling}

In supplier criteria modelling, some criteria can be expressed by concrete values - numbers, while some of them cannot be expressed by numbers. The first group of criteria is called certain (crisp) criteria, while the second group of criteria is called uncertain ones. The first group comprises the following criteria: price per unit, the time of transport and the time of delivery. These values are expressed by money units and time units (hour, minute, second, etc.). Since some criteria values can be expressed by concrete (crisp) values, their modelling is simpler. These values can be expressed by recorded, real data in the companya $\mathrm{a}_{\mathrm{ij}}$, or by monitoring for a longer period of time (3 years). By normalization of supplier integer criteria, the values are reduced to the scale $(0 \div 1)$ that is sufficient for comparison and ranking of supplier values. In this paper, the uncertain criteria fuzzy assessments were described by linguistic expressions that could be presented by triangular fuzzy number $\tilde{V}_{i k}=$ $\left(y ; l_{i k}, m_{i k}, u_{i k}\right) \quad$ with the lower and upper bounds $\mathrm{l}_{\mathrm{ik}}$ and $\mathrm{m}_{\mathrm{ik}}$ and modal value $u_{i k}$, respectively. These values in the domain of triangular fuzzy numbers belong to the real set in the scale $[1 \div 9]$. Uncertain criteria values in this paper were modelled by three or five linguistic expressions, as the author of the text decided in talks with relevant agents, as it will be presented below:

1) The product price is a value obtained by a supplier on the basis of invested material, labour, energy, knowledge, skill, and on the basis of his own profit, taking care of cost price of the same or similar products at the common global market. The product price is expressed by value (money) unit. It has a concrete value and can be presented by concrete (fixed) number.

2) The time of delivery is the time that passed from the moment of accepting an order to the moment of receiving it by a customer. This time is expressed by time units (minute, hour, month, etc.). This value is a discrete one and it is expressed by concrete number of time units.

3) The way of payment is an uncertain value and cannot be defined by a concrete value. The common practice of payment of the purchased goods is to do it in one of the following ways: in advance, one part in advance and the rest on delivery, the whole amount on delivery, a part in cash and another part in compensation. These values are defined by five linguistic expressions, converted into fuzzy numbers, as shown in Fig. 1.

4) The quality of material is an uncertain value and cannot be defined by a concrete value. The quality of material can be defined in one of the following ways: acceptable, very acceptable, good, very good and excellent. These values are defined by five linguistic expressions, as shown in Fig. 1, and they are converted into fuzzy numbers.

5) Suppliers reliability is an uncertain value defined in one of the following ways: satisfactory, good and excellent. These values were defined by three linguistic expressions, as shown in Fig. 2, and converted into fuzzy numbers.
6) Suppliers flexibility is an uncertain value defined in one of the following ways: low, medium and good. These values were defined by three linguistic expressions, as shown in Figure No 2, and converted into fuzzy numbers.

7) Ecological safety of product is an uncertain value that cannot be defined by concrete values. Quality of ecological safety can be defined in one of the following ways: acceptable, bad, average, good, very good and excellent. These values were defined by five linguistic expressions, as shown in Figure No 1, and converted into fuzzy numbers.

8) Supplier location is an uncertain value that is defined in one of the following ways: satisfactory, good and excellent. These values were defined by three linguistic expressions, as shown in Figure No 2, and converted into fuzzy numbers.

9) Previous relations to a supplier is an uncertain value and cannot be defined by a concrete value. Relations to a supplier can be defined in one of the following ways: acceptable, low, medium, good, very good and excellent. These values were defined by five linguistic expressions, as shown in Fig. 1, and converted into fuzzy numbers.

10) Development prospects of a company is an uncertain value defined in one of the following ways: satisfactory, good and excellent. These values were defined by 3 linguistic expressions, as shown in Fig. 2 and converted into fuzzy numbers.

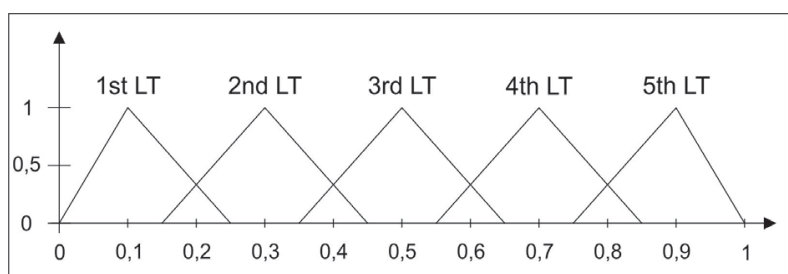

Figure 1 Conversion scale into fuzzy numbers in the case of five linguistic expressions

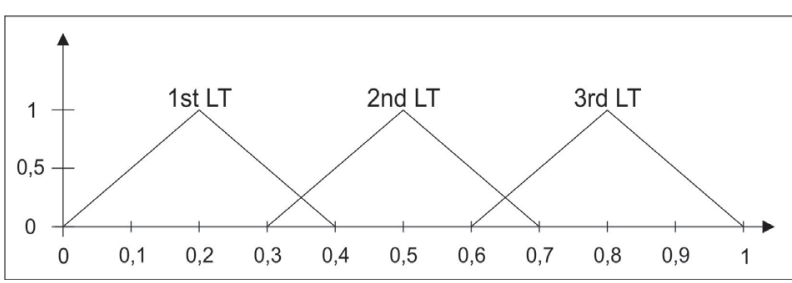

Figure 2 Conversion scale into fuzzy numbers in the case of three linguistic expressions

\subsection{The proposed algorithm for supplier selection}

Proposed model for selection of a supplier of aluminized sheet for car muffler production was presented in several steps:

Step 1. Calculation of weighted criteria vectors was done by applying the procedure presented in Section 3.2.

$\widetilde{W}=\left(W_{j 1}, W_{j 2}, \ldots, W_{j k}, \ldots, W_{j K}\right)$.

Step 2. Conversion of criteria values

a) Conversion of crisp values

- Conversion of values of type max 


$$
a_{i j} \rightarrow r_{i j}=\frac{a_{i j}}{\sum a_{i j}}
$$

- Conversion of values of type min

$a_{i j} \rightarrow r_{i j}=1-\frac{a_{i j}-a^{\min }}{a^{\max }}$

where $a^{\min }=\min _{i} a_{i j}, a^{\max }=\max _{i} a_{i j}$

b) Conversion of linguistic values

- Conversion of linguistic values of type max, according to [24].

$\tilde{V}_{i k}^{n}=\left(\frac{l_{i j}}{u_{j}^{+}}, \frac{m_{i j}}{u_{j}^{+}}, \frac{u_{i j}}{u_{j}^{+}}\right)$,

where: $u_{j}^{+}=\max _{i=1, \ldots, I} u_{i k}, k=K^{1}+1, \ldots, K^{2}$.

- Conversion of linguistic values of type min for cost type criteria minimal value $l_{k}^{\mathrm{min}}$ is divided by values $l_{i k}, m_{i k}$ and $u_{i k}$, according to [24].

$\tilde{V}_{i k}^{n}=\left(\frac{l_{j}^{-}}{u_{i j}}, \frac{l_{j}^{-}}{m_{i j}}, \frac{l_{j}^{-}}{l_{i j}}\right)$,

where: $l_{j}^{-}=\min _{i=1,2, \ldots, I} l_{i k}, k=K^{1}+1, \ldots, K^{2}$. matrix

Step 3. Calculation of weighted normalized decision

$\tilde{V}_{i k}=W_{k} \cdot \tilde{V}_{i k}^{n}$

Step 4. Determination of ideal solutions

a) Determination of positive ideal and negative ideal solutions (PIS and NIS)

Positive ideal and negative ideal solutions were determined by conventional TOPSIS method in the following way:

$V=\left[W_{i k}\right]_{i \times k} i=1,2, \ldots, I, \quad k=1,2, \ldots, K$
$V_{j}^{+}=\max _{j=1,2, \ldots, A} a_{i k}^{n}$,

$V_{j}^{-}=\min _{j=1,2, \ldots, A} a_{i k}^{n}$,

For criteria: $k=1,2, \ldots \ldots, K^{1}$

$A^{+}=\left(V_{1}^{+}, V_{2}^{+}, \ldots, V_{k}^{+}\right)=\left\{\max _{i} V_{i k}(i=1,2, \ldots, K)\right\}$.

$A^{-}=\left(V_{1}^{-}, V_{2}^{-}, \ldots, V_{k}^{-}\right)=\left\{\min _{i} V_{i k}(i=1,2, \ldots, K)\right\}$.

b) Determining FPIS and FNIS by conventional TOPSIS method in the following way:

$\tilde{V}=\left[\widetilde{W}_{i k}\right]_{i \times k^{\prime}}, k=K^{1}+1, \ldots, K^{2}$.

$\tilde{A}^{+}=\left(\tilde{V}_{1}^{+}, \tilde{V}_{2}^{+}, \ldots, \tilde{V}_{k}^{+}\right)=\left\{\max _{i} \tilde{V}_{i k}(i=1,2, \ldots, K)\right\}$.

$\tilde{A}^{-}=\left(\tilde{V}_{1}^{-}, \tilde{V}_{2}^{-}, \ldots, \tilde{V}_{k}^{-}\right)=\left\{\min _{i} \tilde{V}_{i k}(i=1,2, \ldots, K)\right\}$.

where: $\tilde{V}_{i k}^{+}=W_{k} \otimes(1,1,1), \quad \tilde{V}_{i k}^{-}=W_{k} \otimes(0,0,0)$, for each $j=1,2, \ldots, k$.

Step 5. Determining corrected distance from an ideal solution (ASIS)

$\Delta l_{i k}=1-l_{i k}^{\max }$

$\Delta m_{i k}=1-m_{i k}^{\max }$

$\Delta u_{i k}=1-u_{i k}^{\max }$

$\Delta l_{i k}=0-l_{i k}^{\min }$,

$\Delta m_{i k}=0-m_{i k}^{\min }$,

$\Delta u_{i k}=0-u_{i k}^{\min }$.

Obtained values were replaced in the formula for calculating the distance by Euclidian distance.

Step 6. Calculating the distance from PIS, NIS, FPIS and FNIS.

- $\quad$ For crisp values

$d_{i}^{+}=\sum_{k=1}^{K^{1}} \mathrm{~d}\left(V_{k}^{+}-V_{i k}\right), k=1,2, \ldots ., K^{1}$,

$\tilde{d}_{i}^{-}=\sum_{k=1}^{K^{1}} \mathrm{~d}\left(V_{i k}-V_{k}^{-}\right), k=1,2, \ldots \ldots, K^{1}$.

- For fuzzy: Vertex method by Chen [3].

For benefit type criteria:

$\tilde{d}_{i k}^{+}=\mathrm{d}\left(\tilde{V}_{i k}, \tilde{V}_{k}^{+}\right)=\sqrt{\frac{1}{3}\left[\left(\left(u_{k}^{+}-\Delta l_{i k}\right)-l_{i k}\right)^{2}+\left(\left(u_{k}^{+}-\Delta m_{i k}\right)-m_{i k}\right)^{2}+\left(\left(u_{k}^{+}-\Delta u_{i k}\right)-u_{i k}\right)^{2}\right]}$,

for $k=K^{1}+1, \ldots, K^{2}$.

where: $u_{k}^{+}=\max _{k=K^{1}+1, \ldots, K^{2}} u_{i k}, k=K^{1}+1, \ldots, K^{2}$.

For cost type criteria:

$\tilde{d}_{i k}^{-}=\mathrm{d}\left(\tilde{V}_{i k}, \tilde{V}_{k}^{-}\right)=\sqrt{\frac{1}{3}\left[\left(\left(u_{k}^{-}-\Delta l_{i k}\right)-l_{i k}\right)^{2}+\left(\left(u_{k}^{-}-\Delta m_{i k}\right)-m_{i k}\right)^{2}+\left(\left(u_{k}^{-}-\Delta u_{i k}\right)-u_{i k}\right)^{2}\right]}$,

for $k=K^{1}+1, \ldots . K^{2}$.

- The total distance calculated in the following way:

Step 7. Calculation of supplier closeness coefficient:

$\tilde{d}_{i}^{+}=\sum_{k=1}^{K^{1}} \mathrm{~d}\left(V_{k}^{+}-V_{i k}\right)+\sum_{k=K^{1}+1}^{K^{2}} \mathrm{~d}\left(\tilde{V}_{i k}, \tilde{V}_{k}^{+}\right)$,

$\tilde{d}_{i}^{-}=\sum_{\mathrm{k}=1}^{\mathrm{K}^{1}} \mathrm{~d}\left(\mathrm{~V}_{\mathrm{ik}}-\mathrm{V}_{\mathrm{k}}^{-}\right)+\sum_{\mathrm{k}=\mathrm{K}^{1}+1}^{\mathrm{K}^{2}} \mathrm{~d}\left(\widetilde{\mathrm{V}}_{\mathrm{ik}}, \widetilde{\mathrm{V}}_{\mathrm{k}}^{-}\right)$,

where $\mathrm{d}(\ldots)$ distance between two measurements of triangular fuzzy numbers [16].

$C_{i}=\frac{\tilde{d}_{i}^{-}}{\tilde{d}_{i}^{+}+\tilde{d}_{i}^{-}}$

The basic principle of TOPSIS method is that the selected suppliers have the shortest distances from fuzzy 
positive ideal solution $\tilde{\mathrm{d}}_{\mathrm{i}}^{+}$and farthest distances from fuzzy negative ideal solution $\tilde{d}_{i}^{-}$.

Step 8. The procedure of supplier selection by priority list from the best to the worst one.

By ranging values into descending order (from the highest to the lowest) we are getting a priority list of considered suppliers. The supplier having the highest value is the best one and vice versa.

\section{An illustrated example}

In this section we have presented an illustrated example of selection of supplier of aluminized sheet of the company for producing car exhaust systems. The criteria for supplier assessment were presented in Section
3.1 of this paper. Criteria values for the past time recorded in the company were presented in Tab. 1. Criteria values were determined on the basis of monitoring the company's operating in the period of 3 years, as well as on the basis of employees' statements. Uncertain values were represented by linguistic expressions, converted into fuzzy numbers and presented in Tab. 1 .

Calculation of weighted criteria values was done by the procedure from Section 3.2 of this paper and presented in Tab. 2.

By carrying out the steps from 1 to 5 , we have done conversion, normalization, determination of ideal solutions, as well as values for $\mathrm{ASIS}^{+}$and $A S I S^{-}$ presented in Tab. 3 .

Table 1 Criteria values of the company for aluminized sheet provisions

\begin{tabular}{|c|c|c|c|c|c|c|c|c|c|c|}
\hline & $\mathrm{K} 1$ & $\mathrm{~K} 2$ & $\mathrm{~K} 3$ & $\mathrm{~K} 4$ & $\mathrm{~K} 5$ & $\mathrm{~K} 6$ & $\mathrm{~K} 7$ & $\mathrm{~K} 8$ & $\mathrm{~K} 9$ \\
\hline I1 & 2500 & 6 & $(0,0.1,0.25)$ & $(0.35,0.5,0.65)$ & $(0,0.16,0.41)$ & $(0.25,0.5,0.74)$ & $(0.55,0.7,0.85)$ & $(0.58,0.83,1)$ & $(0.25,0.5,0.74)$ & $(0.58,0.83,1)$ \\
\hline I2 & 2800 & 3 & $(0.15,0.3,0.45)$ & $(0.35,0.5,0.65)$ & $(0,0.16,0.41)$ & $(0,0.16,0.41)$ & $(0.75,0.9,1)$ & $(0.25,0.5,0.74)$ & $(0.25,0.5,0.74)$ & $(0.25,0.5,0.74)$ \\
\hline I3 & 2200 & 5 & $(0.15,0.3,0.45)$ & $(0.55,0.7,0.85)$ & $(0.25,0.5,0.74)$ & $(0.25,0.5,0.74)$ & $(0.55,0.7,0.85)$ & $(0,0.16,0.41)$ & $(0.25,0.5,0.74)$ & $(0.25,0.5,0.74)$ \\
\hline I4 & 2250 & 4 & $(0.55,0.7,0.85)$ & $(0.55,0.7,0.85)$ & $(0.25,0.5,0.74)$ & $(0.58,0.83,1)$ & $(0.55,0.7,0.85)$ & $(0.25,0.5,0.74)$ & $(0,0.16,0.41)$ & $(0.58,0.83,1)$ \\
\hline I5 & 2000 & 15 & $(0.55,0.7,0.85$ & $(0.75,0.9,1)$ & $(0.58,0.83,1)$ & $(0.25,0.5,0.74)$ & $(0.35,0.5,0.65)$ & $(0.58,0.83,1)$ & $(0.25,0.5,0.74)$ & $(0,0.16,0.41)$ \\
\hline I6 & 2600 & 6 & $(0.75,0.9,1)$ & $(0.75,0.9,1)$ & $(0.25,0.5,0.74)$ & $(0,0.16,0.41)$ & $(0.75,0.9,1)$ & $(0.58,0.83,1)$ & $(0.25,0.5,0.74)$ & $(0.58,0.83,1)$ \\
\hline
\end{tabular}

Table 2 Values of weighted coefficients

\begin{tabular}{l|l|}
$W_{1}=(0.0916,0.0989,0.1065)$ & $W_{6}=(0.0958,0.1024,0.1090)$ \\
$W_{2}=(0.0945,0.1015,0.1098)$ & $W_{7}=(0.0899,0.0978,0.1048)$ \\
$W_{3}=(0.0946,0.1011,0.1082)$ & $W_{8}=(0.0920,0.0987,0.1067)$ \\
$W_{4}=(0.0929,0.0999,0.1074)$ & $W_{9}=(0.0931,0.0997,0.1076)$ \\
$W_{5}=(0.0970,0.1029,0.1089)$ & $W_{10}=(0.0894,0.0971,0.1056)$ \\
\hline
\end{tabular}

Table 3 Values of converted and normalized supplier criteria with ideal solutions

\begin{tabular}{|c|c|c|c|c|c|c|c|c|c|c|}
\hline & K1 & $\mathrm{K} 2$ & K3 & K4 & K5 & K6 & K7 & K8 & K9 & K10 \\
\hline I1 & 0.8214 & 0.800 & $(0,0.1,0.25)$ & $(0.35,0.5,0.65)$ & $(0,0.16,0.41)$ & $(0.25,0.5,0.74)$ & $(0.55,0.7,0.85)$ & $(0.58,0.83,1)$ & $(0.338,0.676,1)$ & $(0.58,0.83,1)$ \\
\hline $\mathrm{I} 2$ & 0.7143 & 1.000 & $(0.15,0.3,0.45)$ & $(0.35,0.5,0.65)$ & $(0,0.16,0.41)$ & $(0,0.16,0.41)$ & $(0.75,0.9,1)$ & $(0.25,0.5,0.74)$ & $(0.338,0.676,1)$ & $(0.25,0.5,0.74)$ \\
\hline $\mathrm{I} 3$ & 0.9286 & 0.867 & $(0.15,0.3,0.45)$ & $(0.55,0.7,0.85)$ & $(0.25,0.5,0.74)$ & $(0.25,0.5,0.74)$ & $(0.55,0.7,0.85)$ & $(0,0.16,0.41)$ & $(0.338,0.676,1)$ & $(0.25,0.5,0.74)$ \\
\hline $\mathrm{I} 4$ & 0.9107 & 0.933 & $(0.55,0.7,0.85)$ & $(0.55,0.7,0.85)$ & $(0.25,0.5,0.74)$ & $(0.58,0.83,1)$ & $(0.55,0.7,0.85)$ & $(0.25,0.5,0.74)$ & $(0,0.216,0.554$ & $(0.58,0.83,1)$ \\
\hline I5 & 1.0000 & 0.200 & $(0.55,0.7,0.85$ & $(0.75,0.9,1)$ & $(0.58,0.83,1)$ & $(0.25,0.5,0.74)$ & $(0.35,0.5,0.65)$ & $(0.58,0.83,1)$ & $(0.338,0.676,1)$ & $(0,0.16,0.41)$ \\
\hline I6 & 0.7857 & 0.800 & $(0.75,0.9,1)$ & $(0.75,0.9,1)$ & $(0.25,0.5,0.74)$ & $(0,0.16,0.41)$ & $(0.75,0.9,1)$ & $(0.58,0.83,1)$ & $(0.338,0.676,1)$ & $(0.58,0.83,1)$ \\
\hline $\mathrm{A}+$ & 1 & 1 & $(1,1,1)$ & $(1,1,1)$ & $(1,1,1)$ & $(1,1,1)$ & $(1,1,1)$ & $(1,1,1)$ & $(1,1,1)$ & $(1,1,1)$ \\
\hline A- & 0 & 0 & $(0,0,0)$ & $(0,0,0)$ & $(0,0,0)$ & $(0,0,0)$ & $(0,0,0)$ & $(0,0,0)$ & $(0,0,0)$ & $(0,0,0)$ \\
\hline Wi & $\begin{array}{l}(0.0916, \\
0.0989, \\
0.1065) \\
\end{array}$ & $\begin{array}{l}(0.0945, \\
0.1015, \\
0.1098) \\
\end{array}$ & $\begin{array}{c}0.0946, \\
0.1011, \\
0.1098) \\
\end{array}$ & $\begin{array}{c}0.0929, \\
0.0999, \\
0.1074)\end{array}$ & $\begin{array}{c}0.0970, \\
0.1029, \\
0.1089) \\
\end{array}$ & $\begin{array}{l}0.0958, \\
0.1024, \\
0.1090) \\
\end{array}$ & $\begin{array}{l}0.0899, \\
0.0978, \\
0.1048)\end{array}$ & $\begin{array}{c}0.0920, \\
0.0987, \\
0.1067)\end{array}$ & $\begin{array}{l}0.0931, \\
0.0997, \\
0.1076)\end{array}$ & $\begin{array}{l}0.0894, \\
0.0971, \\
0.1056) \\
\end{array}$ \\
\hline ASIS $^{+}$ & $\begin{array}{c}(0.908, \\
0.901, \\
0.891) \\
\end{array}$ & $\begin{array}{c}0.905 \\
0.898 \\
0.890) \\
\end{array}$ & $\begin{array}{l}0.930, \\
0.910, \\
0.893)\end{array}$ & $\begin{array}{l}0.930, \\
0.925, \\
0.893) \\
\end{array}$ & $\begin{array}{l}0.944, \\
0.915, \\
0.891) \\
\end{array}$ & $\begin{array}{l}0.944, \\
0.915, \\
0.891) \\
\end{array}$ & $\begin{array}{l}0.933 \\
0.912, \\
0.895) \\
\end{array}$ & $\begin{array}{l}0.947, \\
0.918, \\
0.893) \\
\end{array}$ & $\begin{array}{l}0.969, \\
0.933, \\
0.892) \\
\end{array}$ & $\begin{array}{l}0.948, \\
0.919, \\
0.894) \\
\end{array}$ \\
\hline ASIS $^{-}$ & $\begin{array}{l}0.072, \\
0.071, \\
0.078) \\
\end{array}$ & $\begin{array}{l}(0.019, \\
0.020, \\
0.022)\end{array}$ & $\begin{array}{c}0.000, \\
0.010, \\
0.027)\end{array}$ & $\begin{array}{l}(0.033, \\
0.050, \\
0.070)\end{array}$ & $\begin{array}{l}0.000, \\
0.016, \\
0.045)\end{array}$ & $\begin{array}{l}0.000, \\
0.016, \\
0.045)\end{array}$ & $\begin{array}{c}(0.031, \\
0.049, \\
0.000)\end{array}$ & $\begin{array}{l}0.000, \\
0.016, \\
0.044) \\
\end{array}$ & $\begin{array}{l}0.000, \\
0.022, \\
0.060) \\
\end{array}$ & $\begin{array}{l}0.000, \\
0.016, \\
0.043) \\
\end{array}$ \\
\hline Tip & $\min$ & $\min$ & $\max$ & $\max$ & $\max$ & $\max$ & $\max$ & $\max$ & $\max$ & $\max$ \\
\hline
\end{tabular}

Table 4 Total distances from ideal solutions

\begin{tabular}{|c|c|c|c|c|}
\hline Supplier & $d_{i k}^{+}$ & $d_{i k}^{-}$ & $d_{i k}^{+}+d_{i k}^{-}$ & $C_{i}$ \\
\hline Supplier 1 & 12.7513 & 1.3457 & 14.0970 & 0.0955 \\
\hline Supplier 2 & 12.6873 & 1.2857 & 13.9730 & 0.0920 \\
\hline Supplier 3 & 12.7446 & 1.3497 & 14.0943 & 0.0958 \\
\hline Supplier 4 & 12.9116 & 1.5037 & 14.4153 & 0.1043 \\
\hline Supplier 5 & 12.7903 & 1.3912 & 14.1816 & 0.0981 \\
\hline Supplier 6 & 12.8785 & 1.5144 & 14.3929 & 0.1052 \\
\hline
\end{tabular}

Table 5 Priority list for supplier selection

Table 5 Priority list for supplier selection
\begin{tabular}{|c|c|c|}
\hline Priority & Supplier & $C_{i}$ \\
\hline 1 & Supplier 6 & 0.1052 \\
\hline 2 & Supplier 4 & 0.1043 \\
\hline 3 & Supplier 5 & 0.0981 \\
\hline 4 & Supplier 3 & 0.0958 \\
\hline 5 & Supplier 1 & 0.0955 \\
\hline 6 & Supplier 2 & 0.0920 \\
\hline
\end{tabular}

Values of total distances from ideal solutions (calculated by Step 6) were presented in Tab. 4 .

The supplier priority list, arranged in the descending order of distance coefficients, was presented in Tab. 5.

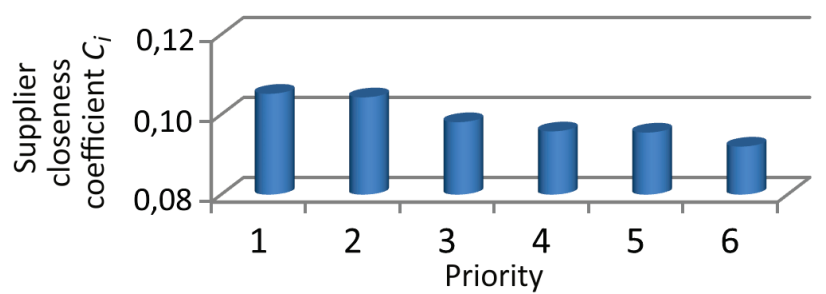

Figure 3 Priority histogram for aluminized sheet supplier selection 


\section{Conclusion}

This paper presents a new, two-phase, multi-criteria methodology for supplier selection, illustrated by the example of a company providing aluminized sheet. The developed methodology was presented as a general supplier selection process by the use of several key criteria dominant for this type of business. The company performs the selection by defined criteria. The criteria that could be measured and presented by crisp values were recorded and determined by the final value. The criteria that could not be defined by the final value were presented by linguistic expressions, by the procedure in Section 3.3 and values converted into fuzzy numbers and calculated by fuzzy algebra.

Criteria weights were determined by fuzzy AHP method and presented in Tab. 2. The values of distances from ideal solution and closeness coefficients were calculated by applying the proposed adapted fuzzy TOPSIS method. Priority list of the considered suppliers in the descending order was formed on the basis of calculated values of closeness coefficients. The priority list values were presented in Tab. 5. From this table one can clearly see which supplier is the best and recommended for further cooperation. From the list presented in Tab. 5 and histogram from Fig. 3, one can see the best supplier is the one with ordinal number 6 and weight 0.1052 . The next one is the supplier with ordinal number 4 and weight 0.1043 . The worst supplier is the one with ordinal number 2 and weight 0.0920 that is not recommended for cooperation.

The proposed model is a simple, fast and reliable procedure enabling a simple selection of the best supplier. This procedure gives a clear image of suppliers, their terms, potentials and activities regarding the chances for cooperation. By knowing this weighted list, managers could easily decide about the directions of business cooperation and who they could make long term plans with. The model can help a customer determine an optimal set of suppliers to cooperate with. This model can be also effective in improvement of supplier selection. A customer can use it as a device in selection of the best supplier. A supplier can use these results from marketing perspective. Specific suppliers achieving high results of prioritization in relation to other suppliers can use these results in promotion of their products. On the other hand, if a supplier is poorly ranked, he can use these results for the purpose of benchmarking.

\section{References}

[1] Tadić, D.; Stefanović, M.; Bohanec, M.; Aleksić, A. Evaluation and ranking of artificial hip prosthesis suppliers by using a two-step fuzzy Delphi and TOPSIS methodology. // The International Journal of Health Planning and Management, HPM-11-00126, 2011, pp. 123.

[2] Bronja, H. Multi-criteria approach to ranking suppliers in the supply chains concept. // Tehnicki vjesnik-Technical Gazette. 18, 3(2011), pp. 393-401.

[3] Chen, C.T. Extensions of the TOPSIS for group decisionmaking under fuzzy environment. // Fuzzy Sets and Systems. 114, 1(2000), pp. 1-9. DOI: 10.1016/S01650114(97)00377-1
[4] Sreekumar, S.; Mahapatra, S. A fuzzy multi-criteria decision making approach for supplier selection in supply chain management. // African Journal of Business Management. 3, 4(2009), pp. 168-177.

[5] Kumar, M.; Vrat, P.; Shankar, R. A fuzzy goal programming approach for vendor selection problem in a supply chain. // Computer and Industrial Engineering. 46, 2(2004), pp. 69-85. DOI: 10.1016/j.cie.2003.09.010

[6] Mahdavi, I.; Mahdavi, A. N., Heidarzade, A.; Nourifar, R. Designing a model of fuzzy TOPSIS in multiple criteria decision making. // Applied Mathematics and Computation. 206, 2(2008), pp. 607-617. DOI: 10.1016/j.amc.2008.05.047

[7] Chou, S. Y.; Chang, Y. H. A decision support system for supplier selection based on a strategy-aligned fuzzy SMART approach. // Expert Systems with Applications. 34, 2(2008), pp. 2241-2253. DOI: 10.1016/j.eswa.2007.03.001

[8] Tang, C. Y.; Chen, S. X. Parameter estimation and bias correction for diffusion processes. // Journal of Econometrics. 149, 1(2009), pp. 65-81. DOl: 10.1016/j.jeconom.2008.11.001

[9] Satty, T. L. The Analytic Hierarchy Process. McGraw-Hill, New York, 1980

[10] Hwang, C. L.; Yoon, K. Multiple Attribute Decision making: Methods and Applications. // Springer, Berlin, 1981. DOI: 10.1007/978-3-642-48318-9

[11] Kelemenis, A.; Askounis, D. A new TOPSIS-based multicriteria approach to personal selection. // Expert System with Applications, 2010. DOI: 10.1016/j.eswa.2009.12.013

[12] Hsieh, T. Y.; Lu, S. T.; Tzeng, G. H. Fuzzy MCDM approach for planning and design tenders selection in public office buildings. // International Journal of Project Management. 22, 7(2004), pp. 573-584. DOI: 10.1016/j.jproman.2004.01.002

[13] Chen, C. T.; Lin, C. T.; Huang, S. F. A fuzzy approach for supplier evaluation and selection in supply chain management. // International Journal of Production Economics. 102, 2(2006), pp. 289-301. DOl: 10.1016/j.jpe.2005.03.009

[14] Torfi, F.; Farahani, Z. R.; Rezapour, S. Fuzzy AHP to determine the relative weights of evaluation criteria and Fuzzy TOPSIS to rank the alternatives. // Applied Soft Computing. $10,2(2010)$, pp. 520-528. DOl: 10.1016/j.asoc.2009.08.021

[15] Zimmermann, H. J. Fuzzy Set Theory and its Applications, Kluwer Nijhoff Publising, Boston, USA, 1996. DOI: 10.1007/978-94-015-8702-0

[16] Sadeghpour, G. B.; Gien, D. La Distance-Dpqet le Coefficient de correlation entre deux Variables Aleatoriesfloues. // Actes de LFA'2001, pp. 97-102.

[17] Awasthi, A. A fuzzy multicriteria approach for evaluating environmental performance of suppliers. // International Journal of Production Economics. 126, 2(2010), pp. 370378. DOI: 10.1016/j.ijpe.2010.04.029

[18] Shemshadi, A.; Toreihi, M.; Shirazi, H.; Tarokh, M.J. Supplier selection based on supplier risk: An ANP and fuzzy TOPSIS approach. // The Journal of Mathematics and Computer Science. 2, 1(2011), pp. 111-121.

[19] Yazdani, M. Risk Analysis for Critical Infrastructures Using Fuzzy TOPSIS. // Journal of Management Research. 4, 1(2012), pp. 1-19.

[20] Chakraborty, C.; Chakraborty, D. A theoretical development on a fuzzy distance measure for fuzzy numbers. // Mathematical and Computer Modelling. 43, 34(2007), pp. 254-261.

[21] Tadic, D.; Milanovic, D. D.; Misita, M.; Tadic, B. New integrated approach to the problem of ranking and supplier selection under uncertainties. // Proceedings of the Institution of Mechanical Engineers B. 225, 9(2011), pp. 1713-1724. DOI: 10.1243/09544054JEM2105 
[22] Dubois, D.; Prade, H. Decision-making under fuzziness, in: Advances in Fuzzy Set Theory and Applications, by (ed.) M. M. Gupta, R. K. Pagade, and P. R Yager, NorthHolland, Amsterdam (1979), pp. 279-302.

[23] Bass, M. S.; Kwakernaak, H. Rating and Ranking of Multiple-aspect Alternatives using Fuzzy sets. // Automatica. 13, 1(1977), pp. 47-58. DOI: 10.1016/00051098(77)90008-5

[24] Shih, H. S.; Shyur, H. J.; Lee, E. S. An extension of TOPSIS for group decision making. // Mathematical and Computer Modelling. 45, 7/8(2007), pp. 801-813. DOI: 10.1016/j.mcm.2006.03.023

[25] Bronja, H. The model of scheduling transportation vehicles in the function of improving transportation in supply chains. // Technics Technologies Education Management. 7, 3(2012), pp. 1063-1071.

[26] Jahanshahloo, G. R.; Hosseinzadeh, L. F.; Izadikhah, M. Extension of the TOPSIS method for decision-making problems with fuzzy data. // Applied Mathematics and Computation. 181, 2(2006), pp. 1544-1551. DOl: 10.1016/j.amc.2006.02.057

[27] Wang, Y. J.; Lee, H. S. Generalizing TOPSIS for fuzzy multiple-criteria group decision-making. // Computers and Mathematics with Applications. 53, 11(2007), pp. 17621772. DOI: 10.1016/j.camwa.2006.08.037

[28] Hwang, C. L.; Yoon, K. Multiple Attribute Decision making: Methods and Applications. // Springer, Berlin, 1981. DOI: 10.1007/978-3-642-48318-9

[29] Kaur, P.; Chakrabortyb, S. A new approach to vendor selection problem with impact factor as an indirect measure of quality. // Journal of Modern Mathematics and Statistics. 1, 1-4(2007), pp. 8-14.

\section{Authors' addresses}

\section{Harun Bronja}

State University of Novi Pazar

Vuk Karadzic b.b.

36300 Novi Pazar, Serbia

Phone: +381638177450

E-mail: harunbronja@gmail.com

\section{Haris Bronja}

State University of Novi Pazar

Vuk Karadzic b.b.

36300 Novi Pazar, Serbia

Phone: +381642046968

E-mail: bronjaharis@gmail.com 